\title{
The Impact of Study Abroad Experiences on Vocational Identity among College Students
}

\author{
Julia F. Kronholz, Debra S. Osborn \\ Florida State University
}

Deciding upon a career choice is a fundamental task of early adulthood (Super, 1981). For some college students, this task may be uncomplicated and rather effortless, while other students may find that deciding upon a career path is a more challenging experience. The National Center for Education Statistics (2004) reported that $21.6 \%$ of U.S. undergraduate students are undecided about their college major. This percentage of undecided students is the largest among students, surpassing the percentage of students who have declared other academic majors (e.g. education, business). Supporting this finding, Gordon (2007) found that $75 \%$ of college students change their undergraduate major at least once, indicating that some college students experience difficulty declaring an academic major. Academic indecision is an important consideration in higher education because there are many negative outcomes of academic indecision. For example, Astin (1975) noted that indecision about major and college retention rates are significantly correlated, with those students who are more undecided dropping out of college at higher rates. More recently, Coll and Stewart (2008) found that higher levels of academic or career decidedness are positively related to retention for college students, while others (Lounsbury, Saudargas, \& Gibson, 2004) found a negative relationship between career decidedness and intention to withdraw from college in an investigation involving 232 college freshmen.

Several studies (Borg, 1996; Brown et al., 2003; Reardon, Folsom, Lee, \& Clark, 2011; Williams \& Winston, 1985) examined the variety of activities that increase career decision-making abilities among college students. For example, job shadowing experiences (Borg, 1996), use of computerassisted career guidance systems (Brown et al., 2003), and enrollment in career courses (Reardon, Folsom, Lee, \& Clark, 2011) are experiences that increase career decision-making abilities in college students. Study abroad is another factor that has shown some preliminary promise in the development of career decision-making and vocational identity (Orahood, Kruze, \& Pearson, 2004; Norris \& Gillespie, 2009). The study abroad experience has been shown to provide personal, academic, and professional benefits for participants (Chapman, 2011; Dwyer, 2004; Dwyer \& Peters, 2004; Gardner, Gross, \& Steglitz, 2009; Gillespie \& Slawson, 2002; Hadis, 2005; Niser, 2010; Orahood, Kruze, \& Pearson, 2004; Preston, 2012).

\section{Study Abroad}

According to the International Institute of Education (Chow, 2010), study abroad is defined as "U.S. citizens and permanent residents who received academic credit at their U.S. home institution for study in another country" (p.11). In a report from the Institute of International Education (IIE; 2011), of the 21 million students attending degree-granting institutions in 2010/2011, 273,996 students participated in a study abroad experience. Over a 20 -year span, this indicates a $232 \%$ rise in 
study abroad participation. Furthermore, in a pilot survey of over 153 institutions of higher education, Niser (2010) surmised that "the number of U.S. students participating in study abroad programs is expected to continue to grow and it seems these programs will become part of mainstream offerings in most institutions" (p. 48).

The majority of current research on the study abroad experience explores the impact of that experience on the personal or psychosocial development of college students. Benefits of study abroad have included increased self-confidence (Black \& Duhon, 2006; Chapman, 2011; Dwyer \& Peters, 2004), independence (Black \& Duhon, 2006), global competency (Dwyer \& Chapman, 2004), open-mindedness and independence (Hadis, 2005), as well as general personal development and well-being (Kuh \& Kauffmann, 1984). Study abroad is also associated with gains in intellectual development, particularly among students with limited or no international experience prior to studying abroad (McKeown, 2009). Many studies have also investigated the connection between study abroad and career variables, such as the development of job skills, employment, and salary (Preston, 2012), likelihood of international employment (Norris \& Gillespie, 2009; Orahood, Kruze \& Pearson, 2004), and belief that study abroad will contribute to employment security upon graduation (Jenkins \& Skelly, 2004). The Institute for the International Educational of Students (IES) reported that $84 \%$ of the 1,008 survey participants indicated that study abroad helped them build job skills necessary to be successful in the workplace (Preston, 2012). Orahood, Woolf, and Kruze (2008) found that the 417 survey respondents valued the skills that were developed as part of a study abroad experience. These skills, such as communication, flexibility, \& adaptability, were seen as important components of work (Orahood, Woolf, \& Kruze, 2008).

The development of professional skills is another empirically supported benefit of a study abroad experience. For example, in Chapman's (2011) investigation of the psychosocial benefits of study abroad, it was found that $90 \%$ of respondents reported feeling as though their study abroad experience prepared them for the "real world." This preparation included the belief that study abroad helped participants in the following ways: to gain interpersonal skills required for the workforce, to further understand the global marketplace, to serve as a resume booster and increase a student's marketability, and to have real world experience that serve as performance examples during job interviews (Chapman, 2011). Similarly, 83\% of 3,400 respondents in Dwyer and Peter's (2004) study investigating the benefits of study abroad indicated that through an international experience, participants acquired a skill set which influenced their career goals. Futhermore, McMillan and Opem (2002) found that 70\% of survey respondents who completed an internship abroad reported that their study abroad experience ignited an interest in a career direction.

Overall, research suggests that the experience of study abroad, combined with academic major and performance, is a desirable experience to recruiters, companies, and employing organizations (Gardner, Gross, \& Steglitz, 2009; Harder et al., 2015; Trooboff, Vande Berg, \& Rayman, 2008). Students also recognize the value of the study abroad experience. They are going abroad in record numbers and expect that a study abroad experience will contribute to their success in employment security upon graduation (Dwyer, 2004; Jenkins \& Skelly, 2004). 


\section{Cognitive Information Processing}

Cognitive Information Processing (CIP; Sampson, Reardon, Peterson, \& Lenz, 2004) is one of the most researched and empirically supported vocational theories. The CIP bibliography (Sampson, Peterson, Reardon, \& Lenz, 2014) reveals over 250 pieces of literature written on the theoretical function and application of this career theory. Because of the depth and breadth of research on CIP to career development, in addition to its well-documented application to career development, this theory is a solid theoretical foundation to apply to this investigation.

CIP aims to assist people in making a career choice while learning how to improve current and future decision-making (Sampson et al., 2004). CIP includes the Pyramid of Information Processing (self and occupational knowledge, decision-making, and executive processing) and the CASVE Cycle, a five-stage methodological approach to decision-making. Each letter corresponds to a particular phase: Communication, Analysis, Synthesis, Valuing, and Execution. CIP has been found to be an effective theory to guide intervention approaches across various populations, including veterans (Bullock, Braud, Andrews, \& Phillips, 2009), young adolescents (Hirschi \& Lage, 2008), international populations (Thrift, Ulloa-Heath, Reardon, \& Peterson, 2012) and middle school students (Osborn \& Reardon, 2006). Given its applicability to many populations, a goal of this research was to examine the degree to which CIP might be applied to students who choose to study abroad. For more information on CIP, the reader is referred to www.career.fsu.edu/techcenter/practitioner/index.html.

\section{Purpose of the Study}

Literature suggests that institutions, students, and employing organizations may view study abroad as one way to gain personal and professional skills necessary to be competitive in today's global marketplace (Gardner, Gross, \& Steglitz, 2009; Harder et al., 2015). Therefore, the purpose of this study is to explore the relationship between study abroad and career decision-making variables guided by CIP theory. The research questions include:

1. To what extent do students attribute changes in different dimensions identified by CIP theory to the study abroad experience?

2. What changes in self-reported vocational identity are attributed to the study abroad experience?

3. What factors of Cognitive Information Processing theory are most predictive of career decision-making following a study abroad experience?

Hypothesis: A study abroad experience will have a significant impact on students' perception of vocational identity. In addition, students will report a positive impact of career decision-making abilities following a study abroad experience.

\section{Method}

\section{Participants}

Participants in this study were students enrolled in a study abroad program affiliated with a large, public research university in the Southeast United States. The email was disseminated to a total of 289 students who studied abroad in Spring 2013 and Spring 2014. 122 students opened the link of the electronic survey, yielding a $42 \%$ response rate. An a priori power analysis was conducted for 
the total $R^{2}$ value for a multiple regression analysis with eight predictor variables, power $=.80$, and an alpha level = .05. G*Power 3.1 (Faul, Erdfelder, Buchner, \& Lang, 2009) indicated a sample size of 109 was necessary to produce a medium effect size $(f=.15$; Cohen, 1988). Of the 122 students who began the electronic survey, 106 complete surveys were obtained yielding a power level of .79.

The age range of participants was 18 to 22 with an average age of 19.9 years old. Participants in this study were $74.6 \%$ female, $21.1 \%$ male, and 1 student identifying as transgender. $64.8 \%$ of the participants identified themselves as white; $17.2 \%$ as Hispanic; $5.7 \%$ as black or African American; 4.1\% as multiracial; $2.5 \%$ as Asian; and .8\% identified as American Indian. $4.9 \%$ of participants chose not to disclose their ethnicity. With the exception of an overrepresentation of females $(74.5 \%$ versus $55.1 \%$ in the total population) and underrepresentation of black/African American participants (4.1\% versus $8.6 \%$ in the total population), these demographic characteristics are representative of the undergraduate population at the university where this study occurred.

Students studied abroad in six different locations: 37.7\% were in Valencia, Spain; 34.4\% in London, England; $17.2 \%$ in Florence, Italy; 2.5\% in Panama City, Panama; $1.5 \%$ in Tianjin, China; $5.9 \%$ of students studied in two different locations; and 1 student who studied in Kibbutz Tzuba, Israel. The duration of the study abroad experience for participants in this study was 16 weeks, a full semester.

\section{University Study Abroad}

The study abroad program at the university in which this investigation was conducted is a robust program, offering over fifty programs in twenty countries across the globe. The program boasts over fifty years of experience providing international education and is often regarded as an exemplar in delivering study abroad experiences for students. Annually, over 1,600 undergraduate and graduate students partake in a study abroad experience with this university's international programs office. Programs offered vary in length, from a one-week immersion over spring break, to a full academic year spent abroad; the most popular programs being a four to six week experience occurring during the summer semester.

Prior to departure, students are required to meet for an on-campus, program-specific orientation that includes information regarding travel, safety, and logistical information. Upon arrival to the host country, students also engage in a second orientation session, focused on the introductions of host-country staff and other students, familiarizing students with important needs (grocery, transportation, language, etc.), and study abroad policies. When students return to the U.S., the international programs office does not offer a formal de-briefing of the study abroad experience for most programs. The only group of students who are required to participate in a home-based debriefing are the first year students who elected to spend their first collegiate year abroad. This session is concentrated more on orienting the students to their home institution and connecting students with campus resources as opposed to processing their year in another country.

\section{Procedure}

Approval from the university's Internal Review Board was granted for this investigation. Participants in this investigation were study abroad participants in the Spring 2013 and 2014 semesters. The survey was distributed electronically at four occasions; in April 2013, May 2013, June 
2013, and finally, May 2014. Participants were informed that researchers were conducting a voluntary survey regarding the effect study abroad experiences have on career decision making variables. To ensure anonymity to the investigator, a staff member from the international programs office emailed the link to participants using student contact information. Survey participants were informed that their responses were anonymous.

\section{Measure}

The primary instrument used to gather data was an electronic survey consisting of ten scaled questions and one open ended question (See Appendix A). The scaled questions were valued at 1 - 4, representing an opinion of "Strongly Disagree, Disagree, Agree, Strongly Agree," with all questions requiring an answer to complete the survey. The open-ended question provided participants a write-in option about their study abroad experience.

Vocational identity was measured with two survey items regarding the respondent's reported stability of their goals, interests, and talents before and after the study abroad experience. Survey questions measuring career decision-making were gathered using the constructs of Cognitive Information Processing theory (Sampson et. al, 2004). The authors of CIP theory were consulted in the development of the survey questions using the Delphi Technique method, which is a systematic structuring process in which experts answer questions in rounds (Bolger \& Wright, 2011). In this study, experts (i.e., the CIP authors) were given CIP-related statements and asked which best represented each CIP constructs. The statements were reviewed in rounds until agreement was reached for one statement to represent each CIP construct. This statement was then used to construct the survey questions (See Appendix A).

\section{Data Analysis}

Because students in this study were a pre-existing group of study abroad participants, random assignment to group was not possible. This study used a mixed-methods approach to obtain quantitative data and qualitative information. By utilizing a mixed-methods approach, statistical procedures suggest outcomes while qualitative feedback provides rich and personal insight regarding the subjects' experience (Gay, Mills, \& Airasian, 2006).

For research question one, descriptive statistics determined the percentage of students who reported changes in various components of CIP theory as a result of a study abroad experience. For research question two, a paired samples t-test determined significant changes in self-reported vocational identity following a study abroad experience. Finally, linear multiple regression was used for the final research question to explore which specific components of CIP theory were most predictive of career decision-making abilities following a study abroad experience.

\section{Results}

Table 1 presents the survey item intercorrelations and standard deviations. All items were significant, indicating that the survey items measured similar constructs, though low VIF $(<10)$ coefficients indicated the intercorrelations were not so highly correlated as to suggest multicollinearity. The Cronbach's alpha for this survey was determined to be $\alpha=.86$. 
Table 1. Survey Item Intercorrelations and Standard Deviations

\begin{tabular}{|c|c|c|c|c|c|c|c|c|}
\hline \multirow[b]{2}{*}{ Variable } & \multicolumn{8}{|c|}{ Intercorrelation } \\
\hline & 1 & 2 & 3 & 4 & 5 & 6 & 7 & 8 \\
\hline (1) Self knowledge & 1 & $.40 * *$ & $.27 * *$ & $.51 * *$ & $.38 * *$ & $.49 * *$ & $.45^{* *}$ & $.44 * *$ \\
\hline (2) Options knowledge & & 1 & $.34 * *$ & $.53 * *$ & $.40 * *$ & $.40^{* *}$ & $.47 * *$ & $.42 * *$ \\
\hline (3) Communication & & & 1 & $.37 * *$ & $.44 * *$ & $.27 * *$ & $.40 * *$ & $.26^{* *}$ \\
\hline (4) Analysis & & & & 1 & $.46^{* *}$ & $.56^{* *}$ & $.59^{* *}$ & $.53 * *$ \\
\hline (5) Synthesis & & & & & 1 & $.60^{* *}$ & $.62 * *$ & $.44 * *$ \\
\hline (6) Valuing & & & & & & 1 & $.78^{* *}$ & $.71 * *$ \\
\hline (7) Execution & & & & & & & 1 & $.65 * *$ \\
\hline (8) Metacognitions & & & & & & & & 1 \\
\hline Means & 3.33 & 2.83 & 3.04 & 3.27 & 2.87 & 3.18 & 2.94 & 3.25 \\
\hline SD & .58 & .79 & .77 & .71 & .84 & .92 & .88 & .70 \\
\hline
\end{tabular}

Table 2 presents the percentages of endorsements for each dimension of CIP following a study abroad experience. Responses have been aggregated to represent combined responses of strongly agree and agree and combined responses of strongly disagree and disagree. Results indicate that over half of the participants reported that the study abroad experience contributed to each CIP variable.

Table 2. Aggregate Percentages

\begin{tabular}{lcc}
\hline & Strongly disagree/disagree & Strongly agree/agree \\
\hline Self-knowledge & 5.7 & 94.3 \\
Options knowledge & 33.0 & 67.0 \\
Communication & 23.6 & 76.4 \\
Analysis & 13.2 & 86.8 \\
Synthesis & 33.0 & 67.0 \\
Valuing & 21.7 & 78.3 \\
Execution & 22.6 & 77.3 \\
Metacognitions & 11.3 & 88.7 \\
\hline
\end{tabular}

Study abroad seems to have had the most reported impact on the Self-Knowledge domain, Analysis component of the CASVE cycle, and Metacognitions. Over 94\% of students agreed that following a study abroad experience they have a better knowledge of values, interests and skills. $86.8 \%$ of students reported a better understanding of how their interests, values and skills relate to making a career choice. Finally, $88.7 \%$ of students agreed as a result of studying abroad, they are thinking more positively about career opportunities. Students indicated that the options knowledge domain and the synthesis component of the CASVE cycle were less impacted following a study abroad experience, with $33 \%$ of students disagreeing with the statement "following a study abroad experience, I know more about career options available to me" and "following a study abroad 
experience, I am now able to narrow down many possible career options to a few that are best for me."

Research question 2: A paired-samples independent t-test was used to determine the perceived difference between participants' vocational identity before and after the study abroad experience. Results (Table 3) indicate a significant positive change in college students' reported vocational identity after a study abroad experience, that is, students reported gains in vocational identity that occurred as a result of the study abroad experience.

Table 3. Paired T-test Comparing Pre/Post Vocational Identity

\begin{tabular}{llllll}
\hline & & Mean & $t$ & Sig. (1-tailed) & Mean difference \\
\hline Student & Pre & 2.840 & -4.937 & $<.001$ & .509 \\
& Post & 3.349 & & & \\
\hline
\end{tabular}

Research question 3: The results of the regression $\left(\mathrm{R}^{2}=.51, \mathrm{~F}(8,97)=12.769, \mathrm{p}<.01\right)$ indicated that the model explained $51 \%$ of the variance in career decision-making. The self-knowledge domain of CIP theory $(\beta=.269, p=.003)$, analysis stage of the CASVE cycle $(\beta=.228, p=.024)$ and the metacognitions domain of the CIP pyramid $(\beta=.301, p=.041)$ were observed to be unique significant predictors of career decision-making abilities after a study abroad experience. See Table 4 for complete results.

Table 4. Predictors of career decision-making

\begin{tabular}{ll}
\hline & Career decision-making \\
\hline Variable & $\beta-$ standardized coefficients \\
\hline Self-knowledge & $.269^{* *}$ \\
Options knowledge & -.169 \\
Decision-making: Communication & .011 \\
Decision-making: Analysis & $.228 *$ \\
Decision-making: Synthesis & .132 \\
Decision-making: Valuing & .031 \\
Decision-making: Execution & .058 \\
Metacognitions & $.301 * *$ \\
$\mathrm{R}^{2}$ & .51 \\
$\mathrm{~F}$ & $12.769 * * *$ \\
\hline$* \mathrm{p} \leq .05 * * \mathrm{p} \leq .01 * * * \mathrm{p} \leq .001$ &
\end{tabular}

\section{Qualitative Responses}

A total of 85 responses from the open-ended question indicated a range of opinions on the study abroad experience. Findings were mixed, in that $21 \%$ of students $(n=18)$ responded that the study abroad experience did not impact their vocational identity or career decision-making while $79 \%(\mathrm{n}=67$ ) of participants reported a direct connection between study abroad, vocational identity, and career decision-making abilities. The themes that emerged from qualitative responses were relatively consistent with survey data. For example, open-ended feedback revealed that a study abroad experience clarified college students' values and interests, a central component in the selfknowledge domain of CIP theory. Participants conveyed both broad and specific thoughts regarding their burgeoning levels of self-knowledge, such as "I learned about myself and who I want to be as a person and what I'm capable of doing" and "I learned I would like to do something working with 
people." An additional theme present was the exposure to other career options, with one respondent noting "Study abroad broadened my career interests - if anything it has made me less aware of what I want to do, it has made me realize how many possibilities there are in the world and that has given me so many more things to question as career paths." Students' responses indicate that exposure to new cultures and industries broadened occupational options rather than clarified them.

Responses also indicated that students admitted growth in psychosocial areas such as selfconfidence, intrapersonal development, and independence, but denied that study abroad impacted career goals in any way. For example, one student wrote, "As a broad curriculum student, my time abroad did not really center around a search for a career path, but rather on learning about my skills and improving upon them in general." Two explanations are possible. First, the mission statement of the international program office emphasizes opportunities for international learning and does not explicitly focus on career decision-making or vocational identity development as a major component of a study abroad experience. The emphasis of skill building as opposed to vocational identity development may have influenced this student's perception of the study abroad experience. In addition, it is possible that these types of responses are indicative of students who have not yet had the opportunity to critically reflect on their study abroad experience and relate their personal gains towards gains in career decision-making and vocational identity. This is evidenced through a response from another student, wherein it was relayed that, "Studying abroad gave me the opportunity to grow as an individual. Because of this, it has helped me to be more confident in my overall life decisions and thus helping with my career choices." This might provide explanation for the lack of literature regarding the impact of study abroad on career decision-making and vocational identity. Reliable data is difficult to obtain if at the time of investigation, students are not yet able to analyze the connections between their study abroad experience and their vocational identity.

\section{Discussion}

The purpose of this study was to determine preliminary findings regarding the effect of a study abroad experience on vocational identity and career decision-making as defined by Cognitive Information Processing (CIP) theory (Sampson et al., 2004). The results revealed that a study abroad experience significantly impacts college students' self-knowledge such as interests, values, and skills, and the capacity to relate self-knowledge to career options. Findings also suggest that following a study abroad experience, students possess a more positive outlook on their career options and report having a clearer picture of career goals, interests, and talents, or vocational identity. These results are consistent with previous findings, which indicate that study abroad shapes personal and career development among college students (Chapman, 2011; Dwyer \& Peters, 2004; Orahood, Kruze \& Pearson, 2004; Orahood, Woolf, \& Kruze, 2008). Specifically, this investigation confirms previous findings of the study abroad experience positively influencing the development of decision-making factors that impact vocational identity.

This study also reveals that CIP theory (Sampson et al., 2004) is an appropriate and useful theoretical framework to explore the relationship between study abroad and career decision-making. CIP has been found an effective theoretical tool in exploring vocational factors for many diverse populations (e.g., Bullock, Braud, Andrews, \& Phillips, 2009; Hirschi \& Lage, 2008; Thrift, UlloaHeath, Reardon, \& Peterson, 2012), and this study expands the populations with which CIP seems 
to be appropriate. Components of CIP theory explained over half of the variance in the study abroad experience with respect to career decision-making. This implies that the study abroad experience promotes gains in students' self-knowledge, understanding their fit in the world of work, and contributes to a developing a more positive outlook regarding career opportunities. These decision-making factors are essential in the development of a strong, stable vocational identity.

While the options domain of CIP theory did not reveal significant changes, the qualitative responses provided explanation for this finding. Themes in responses noted that the study abroad experience opened up career possibilities as opposed to solidifying a career option. It appears as though a study abroad experience helps to clarify self-knowledge while elaborating the level of options-knowledge (Chapman, 2011; Hadis, 2005; McMillan \& Opem, 2002). In this same vein, it is plausible to relate this notion to explain why the synthesis and valuing stage of the CASVE cycle did not reveal significant results. While students gain a better understanding of themselves, they are also gaining expansive knowledge about how their interests, values, and skills fit in the global marketplace. After exposure to new organizations, cultures, or industries, students may feel more information is needed to declare the career options available. Furthermore, as $65 \%$ of the students in this study were between the ages of 18 and 20, it is plausible that these students are not developmentally ready to commit to a career choice as they may be continuing to explore career options and build their identity.

\section{Implications for Practitioners}

These findings present interesting implications for career practitioners, international advisors, and higher educational administrators. Career practitioners and international educators should consider collaborating to help students critically engage in their study abroad experience in a judicious manner. Pre-departure workshops that focus on the development of a career-related study abroad plan might more actively involve students in their growth of self-knowledge or optionsknowledge. Such a plan could provide students with a greater level of personal responsibility and awareness in their career development process.

Additionally, offering an opportunity for self-reflection once students return from abroad may help facilitate a critical analysis of the study abroad experience. Institutions of higher education might implement courses or capstone experiences that teach students how to translate their global involvements to real-world applicability. Supporting Chapman's (2011) recommendations on gaining maximum returns from the study abroad experience, engaging in activities such as these may help students to process their study abroad experience in a more critical manner. The goal is to provide students the ability to synthesize international experiences more intentionally as it relates to vocational identity.

A major finding from this study is the impact on metacognitions as a result of a study abroad experience. Nearly $89 \%$ of respondents endorsed thinking more positively about their career options after studying abroad. Because negative career thoughts are associated with a host of mental health concerns (Walker \& Peterson, 2012), the significance of the study abroad program mitigating negative career thoughts is noteworthy. It appears as though receiving feedback from the world of work and participating in vicarious learning does positively impact negative thinking and the ability to think positively about career options. 


\section{Limitations and Future Research}

While components of this model were found to be significant, the finding of this study must be interpreted with caution due to the presence of several limitations. The primary limitations are with the sample. Participants were college students completing a study abroad experience at one university in the Southeast United States. Certainly, expanding the sample population to other universities may provide the opportunity to glean more information about the effect study abroad experiences have on career decision making variables. Research on this topic may be developed in regards to more specific populations, such as students from religiously affiliated institutions, historically black colleges and universities, or universities from various geographic regions of the United States. Additionally, as $74 \%$ of the participants were female, concerns exist about the generalizability of the results to male students. It is also important to note that this was not a true pre-post experiment, and as such, participants' responses for this survey are reflective. Future studies may reveal more salient data utilizing a pre-post design to measure vocational identity. Finally, including duration of study as a factor might reveal interesting findings. It is plausible that length of time abroad might impact the vocational identity or career decidedness of college students.

To further explore the effect of a study abroad experience on college students' career decisionmaking, researchers may be interested in (1) extending the research design as a pre/post quasiexperimental investigation, (2) expanding the participants to students at other universities in order to increase potential for generalizability, (3) incorporating other aspects of career development such as participation in an international job shadow experiences or career development course taught as part of the study abroad curriculum, or (4) integrating psychosocial aspects in an investigation, for instance, the role of study abroad in the establishment of independence as it relates to vocational identity. Further research on this topic might include investigating the five essential components of career development and career intervention (Brown et al., 2003) experienced during a study abroad experience. It is possible that integrating empirically supported intervention techniques (career counseling, career courses, opportunity to gain occupational experience) might enhance the study abroad experience and its impact on career decision-making and vocational identity. Finally, future research might focus on the comparison of the study abroad experience of students engaged in an internship experience while abroad to those who are not.

In future studies, it would be beneficial to use CIP theory to determine if students who are further along in their studies (i.e., upperclassmen) find that a study abroad experience enhances the Valuing stage of the CASVE cycle or offers the opportunity to execute a career decision. One potential explanation for the lack of significant findings for the Valuing stage in this study might be that because during survey administration, students may not have yet been able to analyze the connections between their study abroad experience and their vocational identity. Further exploration of this may be accomplished by comparing responses from undecided students studying abroad and students engaged in a major-specific study abroad program, or through a longitudinal research design.

Finally, while CIP appeared to be an appropriate theoretical fit for this study, considering these research questions from another theoretical approach would likely provide additional insight into the impact of a study abroad experience and would be a fruitful addition to the career development literature. Bandura (1997) is one example of exploring this topic using another theoretical approach; 
postulating that vicarious learning promotes self-efficacy. It could be supposed that the study abroad experience provides an occasion for vicarious learning, leading to higher levels of selfefficacy, in turn positively impacting career decision-making.

\section{Conclusion}

This investigation aimed to provide preliminary evidence regarding the impact of a study abroad experience on vocational identity and career decision-making among of group of undergraduate college students following a study abroad experience. The objective of this investigation was to enhance the small body of literature on the topic of study abroad and vocational identity, and to specifically investigate the applicability of Cognitive Information Processing theory (Sampson et al., 2004) in that area. Results indicate that, for this population, a study abroad experience is associated with positive outcomes regarding college students' vocational identity and career decision-making. Despite the presence of several potential limitations, this study has added to the knowledge base of the career development field. The findings provide useful information for researchers, career practitioners, and higher education administrators in understanding the impact of a study abroad experience on college students' career decision-making and vocational identity. By providing initial evidence of an experience that bolsters students' career decision-making variables, counselors and administrators can use this information to guide students in enhancing their career decision-making processes and clarifying vocational identity.

\section{Acknowledgments}

The authors would like to extend gratitude to Meghan Greene Penland, International Programs Office at Florida State University, in assistance with this study.

\section{References}

Astin, A. W. (1975). Preventing students from dropping out. San Francisco: Jossey-Bass.

Bandura, A. (1997). Self-efficacy: The exercise of control. New York: Freeman.

Black, H. T. \& Duhon, D. L. (2006). Assessing the impact of business study abroad programs on cultural awareness and personal development. Journal of Education for Business, 81, 140-144.

Borg, R. (1996). Factors determining career choice. European Education, 28/2, 6-20.

Bolger, F. \&Wright, G. (2011). The Delphi technique: Past, present, and future prospects Technological Forecasting and Social Change, 78, 1500-1513.

Brown, S. D., Ryan Krane, N. E., Brecheisen, J., Castelino, P., Budisin, I., Miller, M., \& Edens, L. (2003). Critical ingredients of career choice interventions: More analysis and new hypotheses. Journal of Vocational Behavior, 62, 411-428.

Bullock, E., Braud, J., Andrews, L., \& Phillips, J. (2009). Career concerns of unemployed U.S. war veterans: suggestions from a cognitive information processing approach. Journal of Employment Counseling, 46, 171-181.

Campagna, C. G. \& Curtis, G. J. (2007). So worried I don't know what to be: Anxiety is associated with increased career indecision and reduced career certainty. Australian Journal of Guidance \& Counselling, 17, 91-96.

Chapman, V. V. (2011). Beyond the "bubble:" Study abroad and the psychosocial and career development of undergraduates. The University of Mississippi). ProQuest Dissertations and Theses, 354. Retrieved from http://search.proquest.com/docview/879632035? accountid $=4840$

Childress, L. K. (2009). Internationalization plans for higher education institutions. Journal of Studies in International Education, 13, 289-309. 
Chow, P. (2010). Brazil-U.S. international educational exchange: Data from the Open Doors Report on International Educational Exchange. PowerPoint presentation. Retrieved February 2013, from http://www.iie.org/en/Research-and-Publications/Publications-and-Reports/IIEBookstore/ /media/Files/Corporate/Membership/FAUBAI_2010.ashx

Cohen, J. (1988). Statistical power analysis for the behavioral sciences ( ${ }^{\text {nd }}$ ed.). Hillsdale, NJ: Lawrence Erlbaum.

Coll, K. M., \& Stewart, R. A. (2008). College student retention: instrument validation and value for partnering between academic and counseling services. College Student Journal, 42, 41-56.

Deardorff, D. K. (2006). Identification and assessment of intercultural competence as a student outcome of internationalization. Journal of Studies in International Education, 10, 241-266.

Dwyer, M. (2004). Charting the impact of studying abroad. International Educator, 13, 14-17.

Dwyer, M., \& Peters, C. (2004). The benefits of study abroad. Transitions Abroad, 27, 56-57

Faul, F., Erdfelder, E., Buchner, A., \& Lang, A. G. (2009). Statistical power analyses using G*Power 3.1: Tests for correlation and regression analyses. Behavior Research Methods, 41, 1149-1160.

Gardner, P., Gross, L., \& Steglitz, I. (2009). Translating study abroad experiences for workplace competencies. Peer Review, 11, 19-22.

Gay, L. R., Mills, G. E., \& Airsaian, P. (2006). Educational research: Competencies for analysis and application ( ${ }^{\text {th }}$ ed.). Upper Saddle River, NH: Prentice Hall.

Gillespie, J., \& Slawson, C. (2002). IES outcomes assessment project. Retrieved February 2013, from www.iesabroad.org/system/files/Alumni_Outcomes.pdf

Gordon, V. N. (2007). The undecided college student: An academic career advising challenge (3 ${ }^{\text {rd }}$ ed.). Springfield, IL: Charles C. Thomas.

Green, M. F. (2003). The internationalized campus: A strategic approach. International Educator, 7, 1326.

Hadis, B. (2005). Why Are They Better Students when They Come Back? Determinants of Academic Focusing Gains in the Study Abroad Experience. Frontiers: The Interdisciplinary Journal of Study Abroad, 11, 57-70.

Harder, A., Andenoro, A., Roberts, T. G., Stedman, N., Newberry, M.III, Parker, S. J., \& Rodriguez, M. T. (2015). Does study abroad increase employability? NACTA Journal, 59, 41-48.

Heppner, P. P., Wampold, B. E., \& Kivlinghan, D. M. (2008). Research Design in Counseling (3 ${ }^{\text {rd }}$ ed.). Belmont, CA: Thomson Brooks/Cole Publishing Co.

Hirschi, A. \& Lage, D. (2008). Increasing the career choice readiness of young adolescents: an evaluation study. International Journal for Educational and Vocational Guidance, 8, 95-110.

Holland, J. L., Daiger, D. C., \& Power, P. G. (1980). My Vocational Situation. Palo Alto, CA: Consulting Psychologists Press.

Institute of International Education. (2011). Profile of U.S. study abroad students, 2000/2001 - 2009-10. Retrieved from http://www.iie.org/Research-and-Publications/Open-Doors/Data/US-StudyAbroad/Student-Profile/2000-11.

Jenkins, K. \& Skelly, J. (2004). Study abroad is not enough. Brethren Life and Thought, 49, 257-268.

Lounsbury, J. W., Saudargas, R.A., \& Gibson, L. W. (2004). An investigation of personality traits in relation to intention to withdraw from college. Journal of College Student Development, 45, 517-534.

Kuh, G. K., \& Kauffmann, N. F. (1984, April). The impact of study abroad on personal development of college students. Paper presented at the annual meeting of the American Educational Research Association, New Orleans, Louisiana.

McKeown, J. S. (2009). The first time effect: The impact of study abroad on college student intellectual development. Albany, NY: State University of New York Press.

McMillan, A., \& Opem, G. (2002). Study Abroad: A lifetime of benefits. Retrieved from http://www.iesabroad.org/study-abroad/news/study-abroad-lifetime-benefits 
McQueen, A. (2000, April 21). Education secretary encourages students to study abroad. The Free Lance-Star, p. A11. Retrieved from http:/ / news.google.com/newspapers?nid=9fRKRCJz75UC\&dat=20000421\&printsec $=$ frontpa ge\&hl=en.

National Center for Education Statistics (2004). Percentage distribution of undergraduates by their major field of study and enrollment intensity: 2003-04. Retrieved from http://nces.ed.gov/das/epubs/2007165/showTable2007.asp?rt=p\&tableID=3673\&b=es_03.a $\mathrm{sp} \% 23 \mathrm{p} 1$.

Niser, J. C. (2010). Study abroad education in New England higher education: A pilot survey. The International Journal of Educational Management, 24, 48-55.

Norris, E., \& Gillespie, J. (2009). How study abroad shapes global careers: Evidence from the United States. Journal of Studies in International Education, 13, 382-397.

Orahood, T., Kruze, T., \& Pearson, D. E. (2004). The impact of study abroad on business students' career goals. Frontiers: The Interdisciplinary Journal of Study Abroad, 10, 117-130.

Orahood, T., Woolf, J., \& Kruze, T. (2008). Study abroad and career paths of business students. Frontiers: The Interdisciplinary Journal of Study Abroad, 17, 133-141.

Osborn, D. S., \& Reardon, R. C. (2006). Using the self-directed search: Career explorer with highrisk middle school students. The Career Development Quarterly, 54, 269-273.

Norris, E. M. \& Gillespie, J. (2009). How study abroad shapes global careers: Evidence from the United States. Journal of Studies in International Education, 13, 382-397.

Peterson, G. W., Sampson, J. P., Jr., \& Reardon, R. C. (1991). Career development and services: A cognitive approach. Belmont, CA: Thomson Brooks/Cole Publishing Co.

Preston, K. (2012). Recent graduates survey: The impact of studying abroad on recent college graduates' careers. Retrieved from http://www.iesabroad.org/study-abroad/why/career-benefits.

Reardon, R. C., Folsom, B., Lee, D., \& Clark, J. (2011). The effects of college career courses on learning outputs \& outcomes: Technical report No. 53. Publications. Paper 1. http://diginole.lib.fsu.edu.proxy.lib.fsu.edu/techcenter_publications/1

Sampson, J. P, Jr., Lenz, J. G., Reardon, R. C., \& Peterson, G. W. (1999). A cognitive

information processing approach to employment problem solving and decision-making. The Career Development Quarterly, 48, 3-18.

Sampson, J. P. Jr., Peterson, G.W., Reardon, R.C., \& Lenz, J.G. (2014). Bibliography: A Cognitive information processing (CIP) approach to career development and services. Retrieved from http://www.career.fsu.edu/techcenter/whatsnew/201403CIPBibliography.pdf

Sampson, J. P. Jr., Reardon, R. C., Peterson, G. W., \& Lenz, J. G. (2004). Career counseling and services: A cognitive information processing approach. Belmont, CA: Brooks/Cole.

Super, D. E. (1981). Approaches to occupational choice and career development. In A. G. Watts, D. E. Super, \& J. M. Kidd (Eds.), Career development in Britain. Cambridge: Hobson's Press.

Teranishi, C. (2007). Impact of experiential learning on Latino college students' identity, relationships, and connectedness to community. Journal of Hispanic Higher Education, 6, 52-72.

Thrift, M. M., Ulloa-Heath, J., Reardon, R. C., \& Peterson, G. W. (2012). Career interventions and the career thoughts of pacific island college students. Journal of Counseling and Development, 90, 169-176.

Trooboff, S., Vande Berg, M., \& Rayman, J. (2008). Employer attitudes toward study abroad. Frontiers: The Interdisciplinary Journal of Study Abroad, 15, 17-33.

Uthayakumar, R., Schimmack, U., Hartung, P. J., \& Rogers, J. R. (2010) Career decidedness as a predictor of subjective well-being. Journal of Vocational Behavior, 77, 196-204.

Walker, J. V., \& Peterson, G. W. (2012). Goal instability in relation to career thoughts, decision state, and performance in a career course. Journal of Career Development, 20, 497-506. 
Williams, M. and Winston, R. B. (1985). Participation in organized student activities and work: Differences in developmental task achievement of traditional aged college students. NASPA (National Association of Student Personnel Administrators) Journal, 22, 52-59

Wyman, F. (1997). A predictive model of retention rate at regional two-year colleges. Community College Review, 25, 29-58.

Zakaria, F. (2005). The earth's learning curve; the scientific revolution that began 300 years ago has accelerated exponentially. It is moving so fast that the spread of knowledge defines our times. Nations that learn faster will prosper. But it will take something else--wisdom--to endure. Newsweek International, Atlantic Edition, 6. 


\section{Appendix: Questions and Constructs}

\begin{tabular}{|c|c|}
\hline Question & Construct \\
\hline $\begin{array}{l}\text { Prior to my study abroad experience, I had a clear } \\
\text { and stable picture of my goals, interests, and } \\
\text { talents. }\end{array}$ & Vocational Identity \\
\hline $\begin{array}{l}\text { Because of my study abroad experience, I have a } \\
\text { better knowledge of my interests, values and my } \\
\text { skills. }\end{array}$ & Self-knowledge \\
\hline $\begin{array}{l}\text { Because of my study abroad experience, I know } \\
\text { more about the career options available to me. }\end{array}$ & Occupational knowledge \\
\hline $\begin{array}{l}\text { Because of my study abroad experience, I am more } \\
\text { aware of my need for a career plan. }\end{array}$ & Communication \\
\hline $\begin{array}{l}\text { Because of my study abroad experience, I better } \\
\text { understand how my interests, skills and values } \\
\text { relate to making a career choice. }\end{array}$ & Analysis \\
\hline $\begin{array}{l}\text { Because of my study abroad experience, I am now } \\
\text { able to narrow down many possible career options } \\
\text { to a few that are best for me. }\end{array}$ & Synthesis \\
\hline $\begin{array}{l}\text { Because of my study abroad experience, I feel } \\
\text { more confident telling other important people in } \\
\text { my life about my career choice. }\end{array}$ & Valuing \\
\hline $\begin{array}{l}\text { Because of my study abroad experience, I know } \\
\text { what I need to do to take action on my career plans. }\end{array}$ & Execution \\
\hline $\begin{array}{l}\text { Because of my study abroad experience, I am } \\
\text { thinking more positively about my career } \\
\text { opportunities. }\end{array}$ & Executive processing/Metacognitions \\
\hline $\begin{array}{l}\text { As a result of my study abroad experience, I have a } \\
\text { clearer and more stable picture of my goals, } \\
\text { interests, and talents. }\end{array}$ & Vocational Identity \\
\hline $\begin{array}{l}\text { Is there anything else you would like to share about } \\
\text { how your international experience has or has not } \\
\text { impacted your career choice? }\end{array}$ & Open - ended response \\
\hline
\end{tabular}

